\title{
Ethno archaeological Clues to Stone Exploitation in Ancient Dangme-land, Greater Accra Region, Ghana \\ Fritz Biveridge
}

\author{
Senior Lecturer \\ Department of Archaeology and Heritage Studies \\ University of Ghana, Legon. \\ Email: fbiveridge@ug.edu.gh
}

Submitted: March 19, 2019 / Accepted: July 2, 2019/ Published: December 30, 2019

\begin{abstract}
Dangme-land is naturally replete with abundant stone resources whose exploitation facilitated the peoples' adaptation to their environment. The objective of the researcher in this paper was to investigate for what purposes the ancient indigenous Dangme populations that occupied Sega Hill, Kpone, Shai and Prampram exploited and used stones in the remote past. It also documented the techniques and methodologies utilized by the people to exploit this resource. Data for the study were derived from ethnographic and archaeological investigations and from early European sources relating to the area. The combined evidence revealed that the people of the aforementioned settlements exploited stone for a variety of purposes, such as for the construction of agricultural terraces and protective enclosures against slavers. The ethno archaeological evidence also indicated that the four principal early vocations of the people namely; fishing, crop farming, hunting and trapping were facilitated greatly by the use of a variety of tools manufactured from stone.
\end{abstract}

Keywords: Ethno archaeology, stone blocks, cultural materials, Dangme, European sources

\section{Introduction}

This research investigated how the indigenous populations of Sega Hill, Kpone, Prampram and Shai (Fig. 1) exploited and used stones in the remote past. Sega Hill, Kpone and Prampram are all coastal Dangme settlements located along the Gulf of Guinea in the Greater Accra Region of Ghana. Shai is also occupied by the Dangme but is located approximately $55 \mathrm{~km}$. north of Accra, the capital city of Ghana. Since the early 1970's, several comprehensive archaeological and ethnographic investigations have been conducted by some members of faculty of the Department of Archaeology and Heritage Studies (DAHS), University of Ghana, at some prehistoric Dangme settlements such as Hioweye, Sega Hill, Ladoku, Adwuku and Wodoku (Anquandah, 1982, 1985, 1996; Biveridge, 2005). However, none of 
these studies investigated how the ancient indigenous populations exploited and used stones. The situation has been exacerbated by the fact that ethno historical narratives of the people on the subject are patchy and obscure. It was in the light of this situation that the author initiated this research to investigate and document how these populations exploited this natural resource for their benefit. The study had two overarching objectives. The first was to establish and document how indigenous Dangme populations occupying the above-named research areas exploited and used the abundant stone resources in their environment. The second was to identify the tool kits, methodologies and techniques employed for their exploitation.

Archaeological and ethnographic data constituted the primary data sources used to undertake the study. The former was derived from extensive surface surveys and excavations undertaken at the ancient settlement quarters of the above-named settlements except Shai where no excavation was conducted because the author was unable to secure an excavation permit from the Ghana Museums and Monuments Board (GMMB), the state institution responsible for issuing excavation permits in Ghana. Two units each were excavated at Kpone and Sega Hill. At Prampram, one unit was excavated because of financial constraints. The purpose of the excavation was to recover stone objects of archaeological significance. The archaeological research was undertaken in phases, each spanning approximately two weeks and covered one town. Ethnographic data were derived from 37 respondents, mainly clan elders and selected resource persons settled in the research areas. The author also examined historical sources documented by early European writers some of whom visited the region and interacted with the local people. These documents date to between the mid- $17^{\text {th }}$ to late $20^{\text {th }}$ century. 


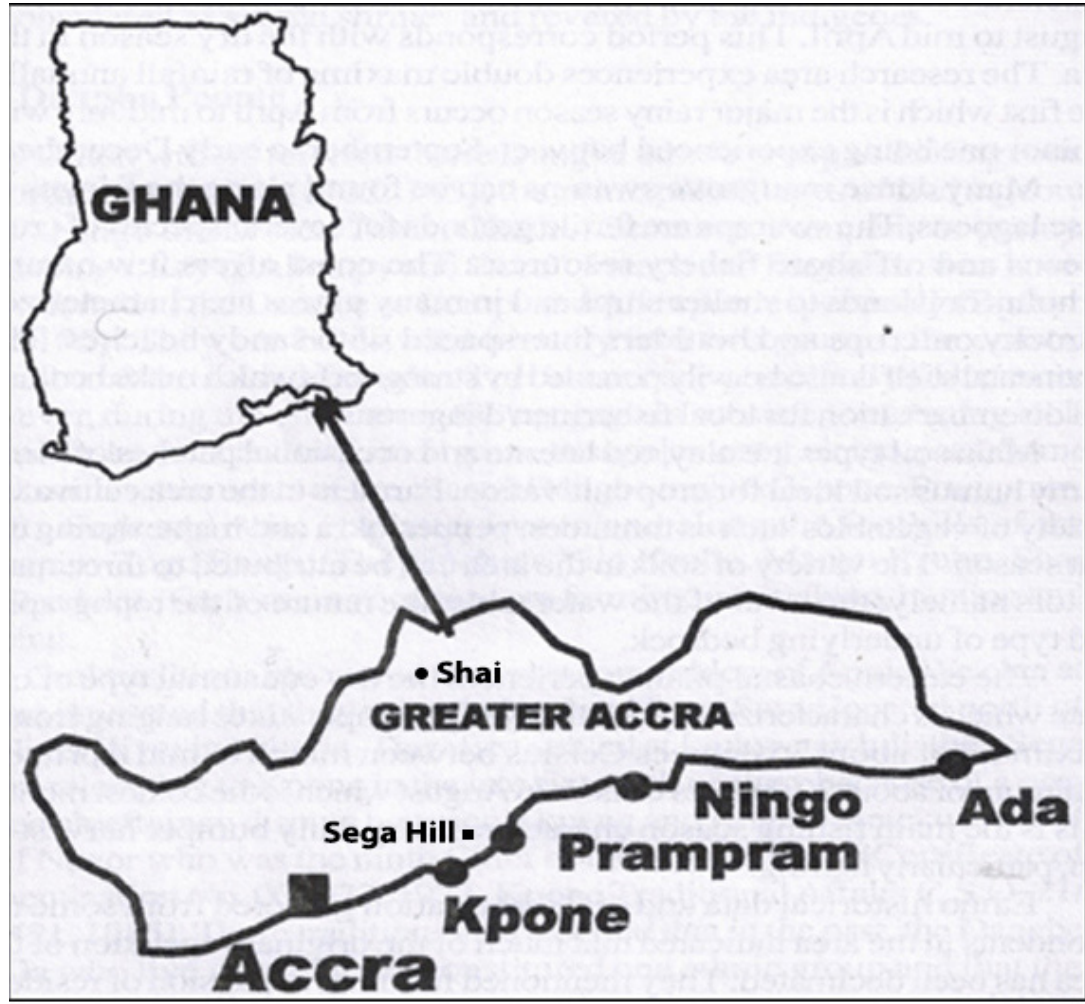

Figure 1: The research areas (Source: Author)

The Dangme can be divided broadly into two groups namely; the inland and the coastal Dangme's. The former live along the foothills of the Akwapim-Togo Range and their main towns are Yilo Krobo, Manya Krobo, Shai and Osudoku. Shai was the ancestral home of several Dangme groups prior to their forceful transplantation onto the Eastern Coastal Plain by English colonizers in 1892. Crop farming, animal husbandry, potting and trading constitute their main vocations. The latter are settled along the Gulf of Guinea and comprise Prampram, Kpone, Ningo and Ada. Deep sea fishing, trading and crop farming are their primary economic activities.

Ethno historical traditions of the Dangme indicate they migrated from external sources before settling at Shai and the Lorlovo Plains in Osudoku (Anquandah, 1996, p. 75). Some places mentioned in Dangme ethno historical traditions as their ancestral homeland include Togo, Dahomey and Yoruba-land (Anquandah, 1982). 
Biveridge, F./Legon Journal of the Humanities Vol. 30.2 (2019)

Historical and linguistic evidence however suggest that they migrated from the Lower Volta Basin in two groups - Se and Le (Boahen, 1977; Anquandah, 1982; Kropp-Dakubu, 1976). Socially, the Dangme are organized into clans based on patrilineal descent, subdivided into localized patrilineages. Some notable sociocultural events of the Dangme include the Dipo puberty rites and celebration of the following festivals: Homowo (Kpone and Prampram), Ngmayem (Krobo) and Asafotufiami (Ada). All of the above-named Dangme groups speak different dialects of the Dangme language, a Kwa branch of the Niger-Congo family of languages.

Early European records (Barbot, 1732; Bosman, 1705; Meredith, 1812) posit that the Dangme played a primal role in the socio-political and commercial affairs of the Gold Coast (now Ghana) during the Atlantic contact and pre-colonial eras. Kpone (Ponnie), Ningo (Lay) and Prampram (Pompena) for example, were important commercial entrepots from where important traditional export commodities notably ivory, salt, gold, and slaves were exchanged and exported enroute to Europe. Novel and exquisite European trade merchandises like glass beads, ceramics, alcoholic and non-beverages, textiles, guns and gunpowder were also channeled through them to inland forest polities between the sixteenth and late nineteenth centuries. A few derelict canons, the architectural ruins of Fort Venon (Prampram), Fort Fredensborg (Ningo) and the foundations of an ancient Danish trade post at Kpone are some vestiges attesting to early Euro-Dangme interaction in the study areas.

Stone as used in the text refers to all hardy concretions of earthy or mineral matter such as granite, quartz and gneiss. Dangme-land is naturally replete with stony boulders and outcrops composed mainly of granite and gneiss. Other less occurring mineral types in the study areas are quartz, hornblende, mica and quartzite. Rocks of the Dahomeyan System underlie the research area. According to Oboli (1998), the geology consists mainly of massive crystalline granulites and gneisses which have undergone extensive metamorphism due to great pressure. Other major rock types unique to the system comprise hornblende, pyroxenes, calcium-scapolite and garnet. Migmatites with subordinate quartz, schist, biotite, schist and other sedimentary rock types constitute the remnants (Kesse, 1985). Much of the coastline consists of flat sandy patches interspersed with large rocky promontories which become visible for several metres off-shore at low tide.

All the coastal settlements named above in the research area are sandwiched between large saline lagoons. From west to east, they comprise Laloi, Gao, Moyo and Sangaw Lagoons. The banks of the lagoons are characterized by dense mangrove swamps which are home to several species of freshwater molluscs and crustaceans. The research area experiences the Dry Equatorial Climate type which 
is characterized by high temperatures ranging from $35^{\circ} \mathrm{C}$. in March to about $25^{\circ}$ C. in August (Dickson \& Benneh, 1973). The area also experiences double maxima rainfall annually and the rainfall pattern is generally sporadic and unreliable, averaging about $800 \mathrm{~mm}$. annually (Dickson \& Benneh, 1973). The relatively impervious underlying rocks make rainwater penetration into the ground difficult; it thus runs off as broad sheet flood during the wet season.

Vegetation cover differs significantly as one moves inland from the coast. For example, along the banks of the lagoons can be found several thick patches of mangroves and waterlogged swamps but further inland, the vegetation is dominated by open grasslands, scrambling and climbing thickets and shrubs occasionally interspersed with tree savanna. The main tree types are Ceiba pentandra, Antiaris Africana, Albizia zygia, Sterculia tragacantha and Baphia nitida.

\section{Relevance of Stone Artifacts for Archaeological Reconstruction}

Stone has a usage history of over two million years. Its hardy and relatively imperishable nature made it the preferred material for making the first undoubted humanly made tools like choppers, flakes, arrowheads, burins (for hunting); hand axes (for farming) and warfare weapons (arrowheads). Others included stone armbands, anklets and beads (for body decoration/ornamentation) and grinders, querns (for food processing). These devices have been discovered at the lowest occupation levels at some of the earliest known settled villages worldwide. Stones are also known to have been used more extensively than any other material, such as for building fortifications and buttressing house foundations. Their small sizes ensured they remained preserved and almost intact in the event of destructive natural and man-made disasters like bushfires, earthquakes, tsunamis and wars. Their study can thus yield veritable clues about past subsistence practices, how ancient sites were used, socio-cultural patterns and their implications for the users.

Flint, quartzite, granite and quartz constituted the preferred rock types used by early man to make tools because of their extra hardy nature which minimize disintegration and breakage upon impact with other hardy materials like bone. Flint can be dated chronometrically by the Thermoluminsence (TL) dating method. Thus, by typological analysis and extrapolation, other artifacts recovered from the same stratum can be relatively dated and the synthesis of human needs can be recognized in the archaeological record.

The earliest stone tool types included choppers and pebbles. They were formed using Oldowan technology which involved knocking one rock particle against another to remove unwanted flakes from the main rock body to have the preferred working edge as well as achieve the desired shape and size. According to 
Joukowsky (2015) and Nicholas and Schick (2010), pebbles and choppers constituted the principal tool types used by the genus Zinjanthropus and Australopithecus to butcher game during the Early Stone Age (Lower Paleolithic) which extends to about three million Y.A. Zinjanthropus and Australopithecus were hunter-gatherers and their remains have been found along parts of the East Africa Rift Valley at sites like Hadder, East Turkana and Olduvia Gorge. These early tool kits were sometimes carried over considerable distances of up to fourteen kilometers (Fagan, 2016). They thus represent a simple form of curation, retaining tools for future use rather than just utilizing convenient stones as chimpanzees do.

With time, stone tools became increasingly complex, evolving into smaller core tools which were sharp-edged and angular to facilitate slitting skins to cut meat and soft plant matter, achieve deep penetration to kill game, and for shaping wood (Fagan, 2016, p. 58). Stone tools may have served additional functions as tools for mashing and hacking. The new tool kits included flakes, scrapers, projectiles and crude axe-like artifacts flaked on either side. According to Joukowsky (2015, p. 309), the consequent interaction of early man and his tools stimulated the increasingly rapid mental evolution of man during the period. It is the view of some anthropologists that sedentism, crop cultivation and the development of several specialists' craft industries like potting, weaving and spinning followed this transition.

About 3,500 Y.A., modern man (Homo sapiens) further developed greater efficiency in stone tool manufacturing using a new technique called pressure flaking which differed considerably from the traditional old way of striking/hammering a small stone against another to remove chips off it (Sharer \& Ashmore, 2005, pp. 346356). In pressure flaking, sharper more delicate tools were made by using a pointed tool to scrape, press and remove finer flakes off the core. These technologically superior tool types were smaller and were intended for a variety of purposes. Other materials known to have been used by early man to make tools included wood from which rudimentary clubs, spears and sticks were fashioned. These tools were used in tandem with stone tools for a long time until about 7,000 years Y.A. when man discovered the technological know-how of smelting iron and forging it into various tool types to enable him adapt/survive in his environment (Toth \& Schick, 2010, pp. 47-61).

In Ghana, several lithic artifacts comprising polished ground stone axes (Nyame akuma), stone beads ("aggrey" beads), stone rubbers, querns, microliths and grinding stones have been recovered together with fauna, molluscs and other artifacts like pottery across all sixteen regions of the country indicating much of modern Ghana was settled during the Late Stone Age. Many of these artifacts 
were found accidentally by expatriate engineers and geologists while exploring, dredging and exploiting mineral resources across the country. Others were found during the construction of roads, railways and other major construction works like dams during the colonial and post-independence eras.

One of the earliest recorded references of the recovery of stone artifacts from Ghana was by the Danish missionary Monrad who found polished ground stone axes at an ancient Late Stone Age settlement at Osu, located in the Greater Accra Region in 1822. Another significant recovery was by Kitson, then Director of the Geological Survey Department. Over a three-year period, he recovered thousands of quartz and quartzite stone tools made by these food producing cultures across the country which he described as, "round ended, flattened pieces of weathered clay stones or burnt clay which are either plain or ornamented with longitudinal, transverse, and oblique cuts, making check patterns of various kinds" (Kitson, quoted in Anquandah, 1982, p. 9). He also noted that the local people occupying the areas where the stone artifacts were found had no idea what these objects were used for, supporting the view that the country was occupied long before the present local peoples arrived. Other personalities who made important lithic discoveries and documented their finds during the early twentieth century included N.R. Junner, Thurstan Shaw, Richard Nunoo, A.W. Lawrence, Richard York, Duncan Mathewson and Oliver Davies.

\section{Methods of Data Collection}

Three surface surveys were conducted on foot during the dry season of the summer of 2016 at each of the settlements. This is a period when much of the overlying vegetation is either withered or dead affording maximum exposure of the ground surface in many places to facilitate direct observation of cultural materials on the ground. Except for Shai where much of the overlying soil was composed of dark brown humus, the other settlements were composed of reddish-brown/darkbrown lateritic soils much of which had undergone extensive disturbance primarily because of farming. This observation was based on the fact that from ground surface to about $10 \mathrm{~cm}$ below ground surface was loose and friable, while soils underlying this level were hard and compacted. The vegetation was secondary, decimated by regular tree felling for fuel wood to smoke fish which is the principal vocation of the women-folk of Kpone and Prampram. Cultural materials retrieved from the surface surveys are shown below in Table 1 . 
Biveridge, F./Legon Journal of the Humanities Vol. 30.2 (2019)

Table 1: Cultural materials retrieved during the surface surveys at Sega Hill,

Prampram, Shai and Kpone together with their quantum and percentage values.

\begin{tabular}{|r|l|r|r|r|r|}
\hline & \multicolumn{1}{|c|}{ Cultural materials } & Sega Hill & Kpone & Prampram & \multicolumn{1}{c|}{ Shai } \\
\hline 1 & Alcoholic beverage bottles & 165 & 4 & 87 & 13 \\
\hline 2 & Querns & 12 & - & 3 & - \\
\hline 3 & Grinders & 8 & 1 & 6 & 4 \\
\hline 4 & Glass beads & 96 & - & 139 & 17 \\
\hline 5 & Stone slabs & 7,922 & 27 & 376 & 503 \\
\hline 6 & Local potsherds & 965 & 96 & 598 & 324 \\
\hline 7 & Imported ceramics & 101 & 41 & 63 & 16 \\
\hline 8 & Bones & 107 & 52 & 121 & 20 \\
\hline 9 & Molluscs' remains & 56 & 2 & 88 & 22 \\
\hline 10 & imported smoking pipes & 34 & - & 29 & 16 \\
\hline 11 & Iron slag & 4 & - & 19 & 4 \\
\hline 12 & Locally made smoking pipes & 63 & 2 & - & 2 \\
\hline 13 & Metal objects & 7 & - & -104 & 29 \\
\hline 14 & Bauxite beads & $\mathbf{9 4 3 8}$ & $\mathbf{2 3 7}$ & $\mathbf{1 6 3 3}$ & $\mathbf{9 7 1}$ \\
\hline & Total & & & -12 \\
\hline
\end{tabular}

Archaeological excavations followed the surface surveys. Sega Hill was the first settlement to be investigated followed by Kpone and Prampram. Sega Hill is currently abandoned but Prampram, Kpone and Shai have been continuously settled from pre-European contact times to present. Ethno historical traditions of the people of Kpone, intimate that Sega Hill was their ancestral home before their relocation, which was necessitated by a chieftaincy dispute between two sons of Angmo Keteku, chief of Sega after his demise (Kpone Traditional Council, C.S.O. 21/22/1421. 1985). The author was assisted during this phase of the research by some students from the Department of Archaeology and Heritage Studies, University of Ghana and locals from the towns investigated. Twenty centimeters arbitrary levels were used to control vertical provenience, while $1 / 4$ inch mesh was used to sieve soil from each unit.

At Sega Hill, the entire site was gridded affording the use of the simple random sampling technique to select grids for excavation. The simple random sampling technique has two main advantages. According to Sharer and Ashmore (2017, p. 133), it "enables a sizeable portion of data to be collected from a given archaeological pool. It also enables each grid in the sampling frame to have a statistically equal chance for selection thus, removing any opportunity for selection bias by the researcher". The quadrats of grids selected for excavation were P33 for 
Unit 1 (1 m. x 2 m.) and W60 for Unit 2 (1 m. x 1.5 m.). The total area excavated was 8 sq. m. representing $0.93 \%$ of the total area gridded. The sterile levels for the two units were $62 \mathrm{~cm}$. and $121 \mathrm{~cm}$. respectively below ground surface. Cultural materials retrieved from the two units at Sega Hill are shown below in Tables 2 and

Table 2: Types and quantum of cultural materials retrieved at Sega Hill - Unit 1. 3.

\begin{tabular}{|c|l|r|r|r|r|r|}
\hline \multicolumn{7}{|c|}{ Unit 1 } \\
\hline & Cultural Material Type & Level 1 & Level 2 & Level 3 & Total & \% values \\
\hline 1 & \multicolumn{1}{|c}{ Bottles } & 17 & 9 & - & 26 & $1.7 \%$ \\
\hline 2 & Local pottery & 106 & 79 & 23 & 208 & $14.1 \%$ \\
\hline 3 & Stone slabs & 23 & 9 & 1 & 33 & $2.2 \%$ \\
\hline 4 & Molluscs & 116 & 87 & 43 & 246 & $16.6 \%$ \\
\hline 5 & Bones & 32 & 56 & 14 & 102 & $6.9 \%$ \\
\hline 6 & Grinders & 2 & 1 & - & 3 & $0.20 \%$ \\
\hline 7 & Glass beads & 13 & 7 & & 20 & $1.35 \%$ \\
\hline 8 & Daub & 17 & 4 & 5 & 26 & $1.76 \%$ \\
\hline 9 & Imported) smoking pipes & 9 & 4 & - & 13 & $0.88 \%$ \\
\hline 10 & Metal objects & 11 & 7 & 2 & 20 & $1.35 \%$ \\
\hline 11 & Imported ceramics & 13 & 9 & - & 22 & $1.49 \%$ \\
\hline 12 & Iron slag & - & 4 & 9 & 13 & $0.88 \%$ \\
\hline 13 & Querns & 3 & - & 1 & 4 & $0.27 \%$ \\
\hline & Total by strata levels & 362 & 279 & 98 & 736 & 1475 \\
\hline
\end{tabular}

Table 3: Types and quantum of cultural materials retrieved at Sega Hill - Unit 2.

\begin{tabular}{|c|c|c|c|c|c|c|c|c|c|}
\hline \multicolumn{10}{|c|}{ Unit 2} \\
\hline & $\begin{array}{c}\text { Cultural } \\
\text { material } \\
\text { type }\end{array}$ & $\begin{array}{c}\text { Level } \\
1\end{array}$ & $\begin{array}{c}\text { Level } \\
2\end{array}$ & Level 3 & $\begin{array}{c}\text { Level } \\
4\end{array}$ & $\begin{array}{l}\text { Level } \\
5\end{array}$ & $\begin{array}{l}\text { Level } \\
6\end{array}$ & Total & $\begin{array}{c}\% \\
\text { values }\end{array}$ \\
\hline 1 & $\begin{array}{l}\text { Bottle } \\
\text { fragments }\end{array}$ & 12 & 23 & 12 & - & - & - & 47 & $3.0 \%$ \\
\hline 2 & Local pottery & 29 & 21 & 4 & 41 & 28 & 9 & 132 & $8.5 \%$ \\
\hline 3 & Stone slabs & 9 & 7 & 2 & 11 & 4 & 1 & 34 & $2.2 \%$ \\
\hline 4 & $\begin{array}{l}\text { Mollusc } \\
\text { remains }\end{array}$ & 9 & 11 & 7 & 23 & 19 & 7 & 76 & $4.9 \%$ \\
\hline 5 & Bones & 23 & 19 & 9 & 3 & 7 & 2 & 63 & $4.0 \%$ \\
\hline 6 & Grinders & - & 2 & 2 & - & - & - & 4 & $0.2 \%$ \\
\hline 7 & Glass beads & 18 & 19 & - & 7 & - & - & 44 & $2.8 \%$ \\
\hline
\end{tabular}


Biveridge, F./Legon Journal of the Humanities Vol. 30.2 (2019)

\begin{tabular}{|c|c|c|c|c|c|c|c|c|c|}
\hline 8 & Metal objects & 1 & 7 & 3 & 1 & - & - & 12 & $0.7 \%$ \\
\hline 9 & Daub & 16 & 23 & 17 & 13 & 16 & 2 & 87 & $5.6 \%$ \\
\hline 10 & $\begin{array}{l}\text { Imported } \\
\text { smoking pipe }\end{array}$ & - & 6 & 3 & - & - & - & 9 & $0.5 \%$ \\
\hline 11 & $\begin{array}{l}\text { Locally } \\
\text { smoking pipe }\end{array}$ & - & 2 & - & - & - & - & 2 & $0.13 \%$ \\
\hline 12 & Gaming disc & - & 1 & - & - & 1 & - & 2 & $0.13 \%$ \\
\hline 13 & $\begin{array}{l}\text { Imported } \\
\text { ceramics }\end{array}$ & 11 & 12 & - & 9 & - & - & 32 & $2.0 \%$ \\
\hline 14 & Iron slag & - & - & 6 & 13 & 9 & - & 28 & $1.82 \%$ \\
\hline 15 & $\begin{array}{l}\text { Palm kernel } \\
\text { shells }\end{array}$ & 106 & 34 & 19 & 12 & 15 & 9 & 195 & $12.6 \%$ \\
\hline \multirow[t]{2}{*}{16} & $\begin{array}{l}\text { Glass window } \\
\text { pane }\end{array}$ & - & 1 & 1 & & - & - & 2 & $10.12 \%$ \\
\hline & $\begin{array}{l}\text { Total by } \\
\text { strata level }\end{array}$ & 234 & 188 & 84 & 134 & 99 & 30 & 769 & 1538 \\
\hline
\end{tabular}

Unlike Sega Hill, Kpone and the ancient settlement quarter at Prampram could not be gridded because of the stony nature of the ground as well as financial constraints. The choice of where to excavate was informed by density of surface artifact scatters. Two units, designated Unit 1 (1 m. x 2 m.) and Unit 2 (1 m. x 2 $\mathrm{m}$.) were opened at Kpone and the total area excavated was 4 sq. m. representing approximately $0.87 \%$ of the total area surveyed. The sterile level of both units was $80 \mathrm{~cm}$ below ground surface. The types and quantum of cultural materials retrieved at Kpone are shown below in Tables 4 and 5.

Table 4: Types and quantum of cultural materials retrieved at Kpone - Unit 1.

\begin{tabular}{|r|l|r|r|r|r|r|r|}
\hline \multicolumn{7}{|c|}{ Unit 1 } \\
\hline & $\begin{array}{c}\text { Cultural } \\
\text { Material Type }\end{array}$ & Level 1 & Level 2 & Level 3 & Level 4 & Total & \% values \\
\hline 1 & Metal object & 2 & - & 2 & 3 & 7 & $0.75 \%$ \\
\hline 2 & Local pottery & 79 & 27 & 19 & 31 & 156 & $16.7 \%$ \\
\hline 3 & Bottle fragments & 2 & 8 & 3 & - & 13 & $1.39 \%$ \\
\hline 4 & Glass beads & 2 & 14 & 3 & - & 19 & $2.0 \%$ \\
\hline 5 & Stone slabs & 39 & 23 & 29 & 21 & 112 & $12.0 \%$ \\
\hline 6 & Molluscs & 143 & 211 & 97 & 34 & 485 & $52.2 \%$ \\
\hline 7 & Bones & 54 & 35 & 26 & 21 & 136 & $14.6 \%$ \\
\hline
\end{tabular}


Biveridge, F./Ethno archaeological Clues to Stone Exploitation in Ancient Dangme-land, Greater Accra Region, Ghana

\begin{tabular}{|l|l|r|r|r|r|r|r|}
\hline 8 & Querns & - & 1 & - & - & 1 & $0.10 \%$ \\
\hline & Total & $\mathbf{3 2 1}$ & $\mathbf{3 1 8}$ & $\mathbf{1 7 9}$ & $\mathbf{1 1 0}$ & $\mathbf{9 2 9}$ & $\mathbf{1 0 0}$ \\
\hline
\end{tabular}

Table 5: Types and quantum of cultural materials retrieved at Kpone - Unit 2,

\begin{tabular}{|r|l|r|r|r|r|r|r|}
\hline \multicolumn{9}{|c|}{ Unit 2 } \\
\hline & $\begin{array}{l}\text { Cultural } \\
\text { Material Type }\end{array}$ & Level 1 & Level 2 & Level 3 & Level 4 & Total & \% Values \\
\hline 1 & Local pottery & 121 & 78 & 41 & 36 & 276 & $27.1 \%$ \\
\hline 2 & Stone slabs & 21 & 10 & 3 & 7 & 41 & $4.03 \%$ \\
\hline 3 & Molluscs remains & 97 & 111 & 63 & 21 & 292 & $28.7 \%$ \\
\hline 4 & Bones & 77 & 34 & 21 & 23 & 155 & $15.2 \% \%$ \\
\hline 5 & Iron slag & 4 & 12 & 15 & 9 & 40 & $3.93 \%$ \\
\hline 6 & Glass beads & 2 & 4 & - & - & 6 & $0.58 \%$ \\
\hline 7 & Grinders & 1 & - & 1 & - & 2 & $0.19 \%$ \\
\hline 8 & $\begin{array}{l}\text { Imported } \\
\text { smoking pipes }\end{array}$ & 3 & 5 & 2 & - & 10 & $0.98 \%$ \\
\hline 9 & $\begin{array}{l}\text { Palm kernel } \\
\text { shells }\end{array}$ & 24 & 81 & 16 & 23 & 144 & $14.15 \%$ \\
\hline 10 & $\begin{array}{l}\text { Imported } \\
\text { ceramics }\end{array}$ & 2 & 12 & - & - & 14 & $1.37 \%$ \\
\hline 11 & Bottle fragments & 13 & 23 & - & - & 36 & $3.53 \%$ \\
\hline 12 & Coin & 1 & - & - & - & 1 & $0.098 \%$ \\
\hline Total & $\mathbf{3 6 6}$ & $\mathbf{3 7 0}$ & $\mathbf{1 6 2}$ & $\mathbf{1 1 9}$ & $\mathbf{1 0 1 7}$ & $\mathbf{1 0 0}$ \\
\hline
\end{tabular}

One unit designated Unit $1(1 \mathrm{~m} . \times 3 \mathrm{~m}$.$) was excavated at the ancient$ settlement quarter at Prampram. Unlike Sega Hill, much of the ground surface at Prampram was bereft of surface artifact scatter except for 12 mounds which appeared to be collapsed house structures. The total area excavated was $3 \mathrm{sq} . \mathrm{m}$. representing $1.2 \%$ of the area surveyed and the sterile level for Unit 1 was 160 $\mathrm{cm}$. below ground surface. The stratigraphy at Prampram comprised a mix of very large stone boulders in very compacted soils which significantly slowed down the excavation work and made artifact recovery difficult. The types and quantum of cultural materials retrieved are shown below in Table 6 . 
Biveridge, F./Legon Journal of the Humanities Vol. 30.2 (2019)

Table 6: Types and quantum of cultural materials retrieved at Prampram - Unit 1.

\begin{tabular}{|c|c|c|c|c|c|c|c|c|c|c|c|}
\hline \multicolumn{12}{|c|}{ Unit 1} \\
\hline & $\begin{array}{l}\text { Cultural } \\
\text { material } \\
\text { types }\end{array}$ & $\begin{array}{l}\text { Level } \\
1\end{array}$ & $\begin{array}{l}\text { Level } \\
2\end{array}$ & \begin{tabular}{|l} 
Level \\
3
\end{tabular} & $\begin{array}{l}\text { Level } \\
4\end{array}$ & $\begin{array}{l}\text { level } \\
5\end{array}$ & \begin{tabular}{|l|} 
Level \\
6
\end{tabular} & $\begin{array}{l}\text { Level } \\
7\end{array}$ & $\begin{array}{l}\text { Level } \\
8\end{array}$ & Total & $\begin{array}{l}\% \\
\text { value }\end{array}$ \\
\hline 1 & $\begin{array}{l}\text { Bottle } \\
\text { fragments }\end{array}$ & 9 & 13 & 45 & 61 & 33 & - & - & - & 161 & $7.6 \%$ \\
\hline 2 & Local pottery & 39 & 57 & 34 & 121 & 153 & 32 & 16 & 19 & 471 & $22.3 \%$ \\
\hline 3 & Stone slabs & 3 & 7 & 9 & 11 & 6 & 3 & - & 1 & 40 & $1.8 \%$ \\
\hline 4 & $\begin{array}{l}\text { Mollusc } \\
\text { remains }\end{array}$ & 145 & 207 & 211 & 57 & 43 & 10 & 21 & 9 & 703 & $33.3 \%$ \\
\hline 5 & Bones & 31 & 12 & 7 & 7 & 9 & 13 & 7 & 6 & 92 & $4.3 \%$ \\
\hline 6 & $\begin{array}{l}\text { Palm kernel } \\
\text { shells }\end{array}$ & 99 & 43 & 21 & 52 & 11 & 9 & 14 & 21 & 270 & $12.7 \%$ \\
\hline 7 & Glass beads & 13 & 21 & 32 & 12 & 3 & - & - & - & 81 & $3.8 \%$ \\
\hline 8 & Querns & - & - & 1 & - & 2 & - & - & - & 3 & $0.14 \%$ \\
\hline 9 & Metal objects & 4 & 7 & 13 & 31 & 19 & 2 & 3 & - & 79 & $3.7 \%$ \\
\hline 10 & $\begin{array}{l}\text { Imported } \\
\text { ceramics }\end{array}$ & 12 & 16 & 9 & 21 & 19 & - & - & - & 77 & $3.6 \%$ \\
\hline 11 & Daub & 5 & 11 & 7 & 14 & 2 & 6 & 2 & 1 & 48 & $2.2 \%$ \\
\hline 12 & $\begin{array}{l}\text { Imported } \\
\text { smoking } \\
\text { pipes }\end{array}$ & 13 & 21 & 10 & 17 & 5 & - & - & - & 66 & $3.1 \%$ \\
\hline 13 & Iron slag & - & - & - & - & - & 3 & 7 & 1 & 11 & $0.52 \%$ \\
\hline 14 & Grinders & - & - & 1 & - & - & 2 & - & - & 3 & $0.14 \%$ \\
\hline 15 & Writing slate & - & 1 & 2 & - & - & - & - & - & 3 & $0.14 \%$ \\
\hline 16 & $\begin{array}{l}\text { Mirror } \\
\text { fragment }\end{array}$ & - & - & 1 & - & - & - & & - & 1 & $0.004 \%$ \\
\hline 17 & Dress button & - & - & 1 & - & - & - & - & - & $\underline{1}$ & $0.004 \%$ \\
\hline To & & 373 & 416 & 404 & 404 & 305 & 80 & 70 & 58 & 2110 & 100 \\
\hline
\end{tabular}

The purpose of the ethnographic research was to facilitate the comparative study of stone devices from archaeological and ethnographic contexts. It was also to discover if they shared similar attributes to suggest they were made by the same ethnic group. A total of 37 respondents consisting of 21 males and 16 females, aged $57-91$ years from different families and occupations were interviewed. They included fishermen, traditional priests and priestesses, fishmongers, traditional medical practitioners, birth attendants, farmers and canoe builders. All the respondents interviewed resided at the ancient settlement quarters of Kpone, Shai and Prampram where traditional norms, values and customs are highly regarded, appraised and practiced despite the strong in-roads made by Christianity and 
globalization. They were thus considered a formidable group from whom data about the past could be derived. Majority of the respondents were not fluent in English and could not express themselves properly in that language. The interviews, which were recorded on tape, were therefore conducted in Ga and Dangme which are the principal medium of communication in that quarter. A five-page questionnaire was also devised to guide the ethnographic investigation and all respondents answered the same questions. The recordings were later played-back and transcribed from the Dangme/Ga languages to English by the author who speaks both languages fluently.

\section{Discussion}

It appears from the combined evidence (archaeological, ethnographic and historical data) that ancient Dangme populations settled in the research areas partly because of their abundant stone resources. Other factors probably included fertile soil and plentiful wildlife resources. Research by several scholars (Anquandah, 1979, 1982, 1986, 1987, 1996; Gblerkpor, 2005; Biveridge, 2005) in the research areas clearly indicate that stone slabs/blocks constituted an integral raw material in Dangme traditional architecture in the past. Notable edifices known to have been built with stone blocks/slabs included agricultural terraces, compound walling systems, house foundations and fortifications. At Sega Hill, 2,929 stone slabs were noted by the researcher. Out of this number, 217 were retrieved from excavations. The bulk were composed of granite and gneiss and were not standardized in shape and size. The blocks appeared to have been hacked from the several rocky outcrops along the beachfront because colourations and joint formations were similar. Two indigenes of Kpone and Prampram, Oglietse (pers. com. 14 ${ }^{\text {th }}$ June, 2016) and Ablade $\left(26^{\text {th }}\right.$ June, 2016) posited that the smaller slabs were utilized as floor tiles inside rooms and in the vicinity of house compounds whilst the large/thick ones were used as buttresses to support house foundations. This construction style according to the respondents curbed gully erosion around house foundations. Anquandah (1986, p. 67) found similar stone slabs of what appeared to be "a very large dwelling complex of a notable personality with a sizable family" which measured $25 \mathrm{~m}$. (east to west) and $20 \mathrm{~m}$. (north to south) during pre-excavation surveys at Adwuku south west. The complex contained granary platforms, sleeping rooms and courtyards constructed with stone slabs. Anquandah (1987, pp. 233 - 234) asserted:

"The entire complex in its original state was well protected like a mini citadel. It had an entrance with a gate on the western front with a staircase of granite slabs leading to the entrance. What emerges is that the surface structural arrangements belong to the $18^{\text {th }}-19^{\text {th }}$ century and they consist of mud structures erected on 
granite stone slabs, paved with floor tiles, each measuring on the average $20 \mathrm{~cm} . \mathrm{x}$ $10 \mathrm{~cm}$. and manufactured by local potters using coarse local clay."

Stone blocks also appeared to have constituted the primary resource for the construction of secret fortified communal sanctuaries in ancient Dangme-land. These structures some of which were monumental such as those at Hiowey and Adwuku Hills were free-standing defensive walling enclosures, erected by laying course by course, well-fitting granite blocks, one atop another between rock boulders till the desired height and lengths were achieved. A small opening at one end served as the entrance. John Agbo Opata (pers. com, 16 $6^{\text {th }}$ July, 2016), an indigene of Doryumu intimated that his great grandfather, one of several Dangmes' forcefully transplanted from Hiowey Hill by the British in 1892, before his passing, told him that during their sojourn at Hiowey Hill, the entire community regularly undertook stone gathering exercises from their environs which were intentionally piled midway along major pathways leading to their hill top settlements. Stones were also piled across difficult to access locations along the edges of steep cliffs where the community had a clear visible advantage from their secret hill-top encampments. These strategic hide-outs together with their several stone compilations were purposely and readily accessed and hurled against slavers and other enemy groups intent on attacking them. Nii Affum Atteh (pers. com. $2^{\text {nd }}$ May, 2017), a 93 year old indigene of Doryumu and a farmer by occupation also posited that traditional hunters in the past were obliged by custom to make concerted efforts during hunting expeditions to seek, discover and bring to the knowledge of clan elders natural crevices within numerous rock boulders and rock shelters they encountered. According to Atteh, the purpose of discovering protective shelters was to utilize them as safe havens for women and children during crisis periods. Their locations were known to only a few and not disclosed to the community for security reasons.

A total of 12 stone grinders/milling stones (fig. 2)) and 6 querns were retrieved from the archaeological record. It is also worth noting that all 27 homes visited to derive ethnographic data still used traditional grinders to process vegetables and other botanical resources despite the popularity of electronic blenders. The bulk of the grinders and querns recovered at Kpone, Prampram and Sega Hill were composed of granite or gneisses. However, a few were composed of quartzite. The grinders appeared to have been hacked from the numerous rock boulders along the beachfront because in terms of colour, linear markings and joint formations, they appeared to be similar.

Grinders from the study areas can be classified broadly into two types namely; mobile and stationery grinders. The former were small in size, approximately $25 \mathrm{~cm}$. (breadth) $\times 7 \mathrm{~cm}$. (height) $\times 35 \mathrm{~cm}$. (length). They were of no definite shape, though 
23 (representing 85.1\%) were roughly rectangular shaped. Only 7 of the latter were discovered in the research areas. They measured averagely $120 \mathrm{~cm}$. (length) x $12 \mathrm{~cm}$. (width) x $86 \mathrm{~cm}$. (breadth) and were naturally fixated to underlying bedrocks. The latter type also had 6 - 11 segmented depressions, each measuring approximately $3-5 \mathrm{~cm}$ deep along the grinding areas indicating about 6 to 11 persons probably used it in tandem in the past to grind. The stationary grinders were probably communally owned because unlike the mobile grinders, they were located in open spaces outside individual homes. Unlike the stone grinders, all the recovered querns were broken almost in half. A close examination with a hand magnifying glass revealed several linear striations along the grinding areas suggesting extensive and continuous usage over a long period of time.

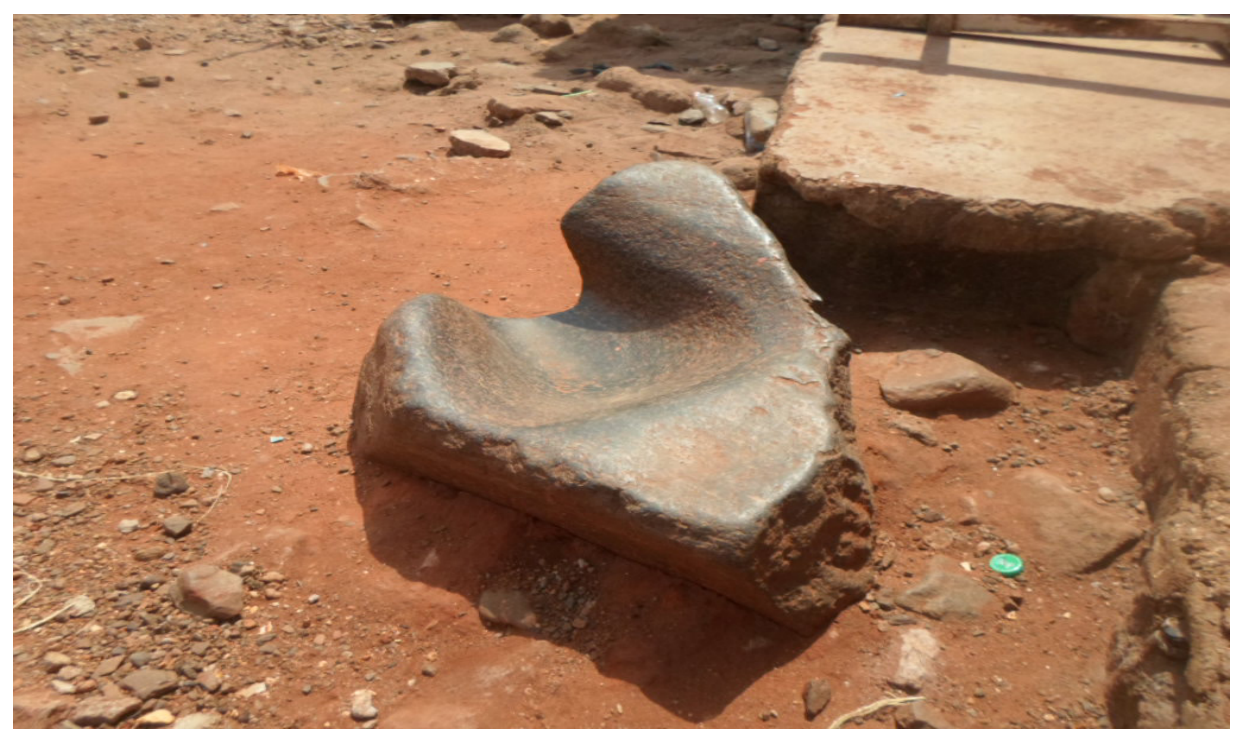

Figure 2: Part of a stone grinder from Kpone (Picture: Author).

Archaeological and ethnographic investigations by Anquandah (1986) at Le and Shai revealed that Dangme groups that settled in the area also utilized another type of stone milling device, which is different from that described above to process staples and herbs. He noted that this rare milling equipment had been recognized only because of its survival in the ethnographic record. In a paper titled Accra Plains, Dangmeland: A case study in the eclectic approach to archaeological and historical studies, Anquandah (1987, p. 80) asserted:

By the first half of the seventeenth century, several early settlements at Le and Shai had developed into urban complexes characterized by mud and stone houses, 
Biveridge, F./Legon Journal of the Humanities Vol. 30.2 (2019)

agricultural terraces, stone walling and occasional fortifications, and each house had milling equipments locally called blemagiji that was constructed from wood, mud and grinding stones.

Anquandah's (1986) excavations revealed that stone was an important raw material for the production of several accoutrements/tools like grinders and scrappers in the research areas in the remote past. The type of stone exploited however, varied from community to community and depended on the intended purpose. According to Nene Abladu Attiope (pers. com. 26 $6^{\text {th }}$ June, 2016), a respected 82 year old retired fisherman resident at James Town, a suburb of Kpone, tapering " $T$ " shaped stone hooks made primarily from water worn pebbles collected from the beachfront constituted an integral part of the tool kit of fisher-folks who plied their trade along the Kpone-Keta coastal stretch in the past. According to the above-named respondent, beach pebbles were the preferred media because of their durability which allowed for repetitive usage. It was also relatively harder and heavier allowing them to submerge faster compared to other media like wood and bone.

Nene Abladu Attiope intimated that the tapering " $T$ " shape was achieved by detaching bits and pieces of flakes off the original pebble by knocking it against another pebble or a hammer head. The purpose was to achieve an almost " $T$ " shaped stone tool with pointed ends and sharp edges at right angles to the long axis. The resulting jagged-edges made a most effective lock-in tool capable of choking, constricting and inflicting injuries inside the throat of fish while it struggled to free itself. The device was secured to vegetal twinges made out of the fibrous branches of Ulva lobata, a soft but strong seaweed belonging to the phylum Chorophyta. Locally called womogmo, it grows naturally and is abundant along the eastern coastal belt where it is generally considered a nuisance/impediment to fishing. Nene Abladu Attiope further intimated that after harvesting, the branches were tied together at vantage points to achieve a desired length after which it was sun-dried for about two weeks to make it strong. The twinge enabled one end of the " $T$ " shaped stone trap to be lowered into, or raised from the sea by the fisherman who held onto the other end. The soft fibrous tissue also allowed for tautness to facilitate drawing upwards after it had caught fish. The inedible offal's of molluscs were oftentimes tied to the ends that submerged in water and served as bait to trap some deep sea fish species in the past (Nene Abladu Attiope, pers. com. 29 $9^{\text {th }}$ May, 2017. Another respondent Nii Tetteh Angmo (pers. com. 27 $7^{\text {th }}$ May, 2017), a 78 year old indigene of Kpone but currently residing at Prampram, during their childhood years, he and other apprentice colleague fishermen used sharp-edged pointed stone lances secured by vegetal twinges to long wooden poles (fig. 3) to spear freshwater 
fishes in the Gao and Laloi Lagoons. To make the tool more effective, the edges of the lancets were sometimes grounded and polished on stone blocks to produce finer and tougher cutting edges than could not be achieved by chipping only.

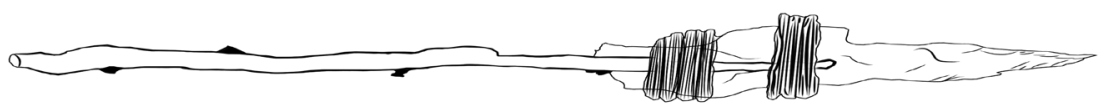

Figure 3: Artistic illustration of the stone lance described by Nii Tetteh Angmo (Drawing: author).

Nii Tetteh Angmo (pers. com. 12 July, 2016) also informed the author that they employed two methods in the past to secure their canoes on-shore after berthing to prevent them from being washed off-shore during rain and wind storms. The first involved securing one end of a rope to a canoe and securing the other end to weighty stone boulders submerged in the ocean close to the coastline (fig. 4). The other assured method involved securing one end of a rope to a canoe and tying the other end around any of the many rocky boulders or coconut trees located off-shore.

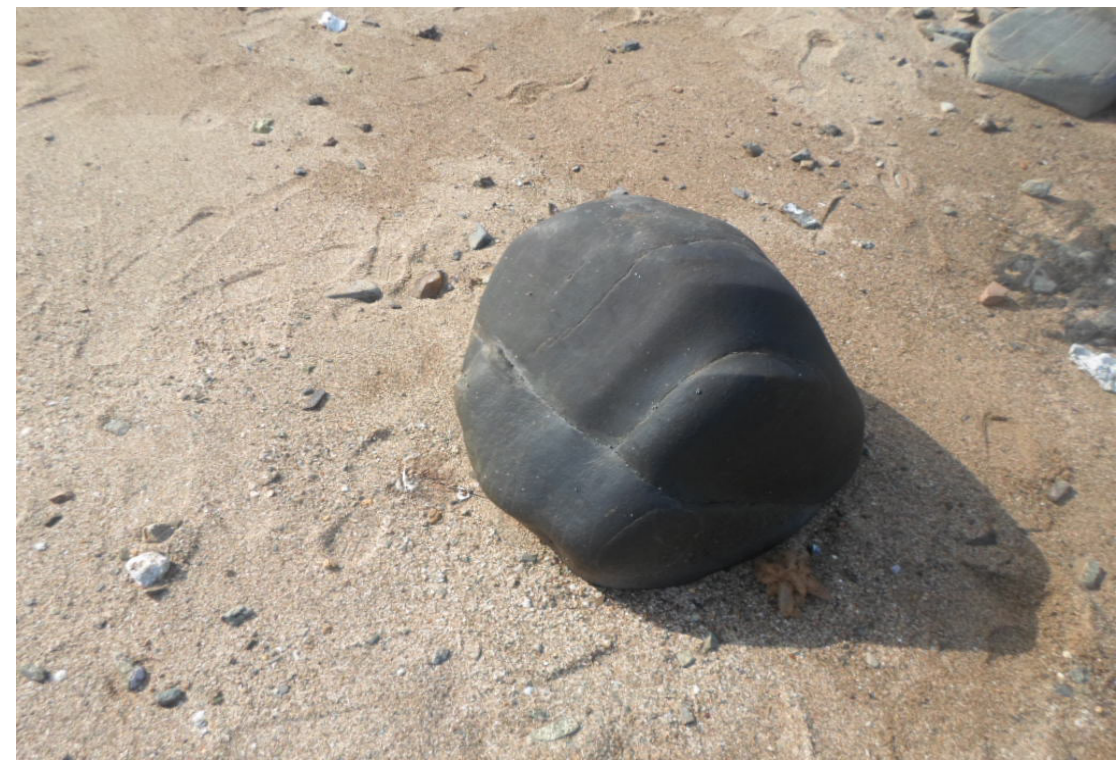

Figure 4: A stone anchor from Prampram beach. Note the smooth horizontal indentation/notch on the upper right side caused by regular weighty suspension of rope attachments along that segment (Picture: Author). 
Another respondent Mr. Attiapa Otetse (pers. com. 27 $7^{\text {th }}$ July, 2017), a retired school teacher and part-time hunter from Shai informed the author that hunters in this home area in the past utilized stone blocks as anchors to prevent loss of traps and game. According to the above named respondent, some animals like deer, giant rat and grasscutter sometimes struggled to disengage/free themselves from traps they had been caught in. In the process, these animals occasionally dragged the traps away from the place where the hunter originally set them to die elsewhere, leading to loss of both trap and game.

At the ancient settlement quarters of Kpone and Prampram, rocks with natural notches/indentations were sometimes utilized as watering and feeding troughs for chickens, goats and sheep (fig. 5). Out of 35 household visitations (Kpone -21 and Prampram - 14), 23 used these stone watering troughs. The study also revealed that in some households, disused stone grinders were oftentimes not discarded but used for this purpose.

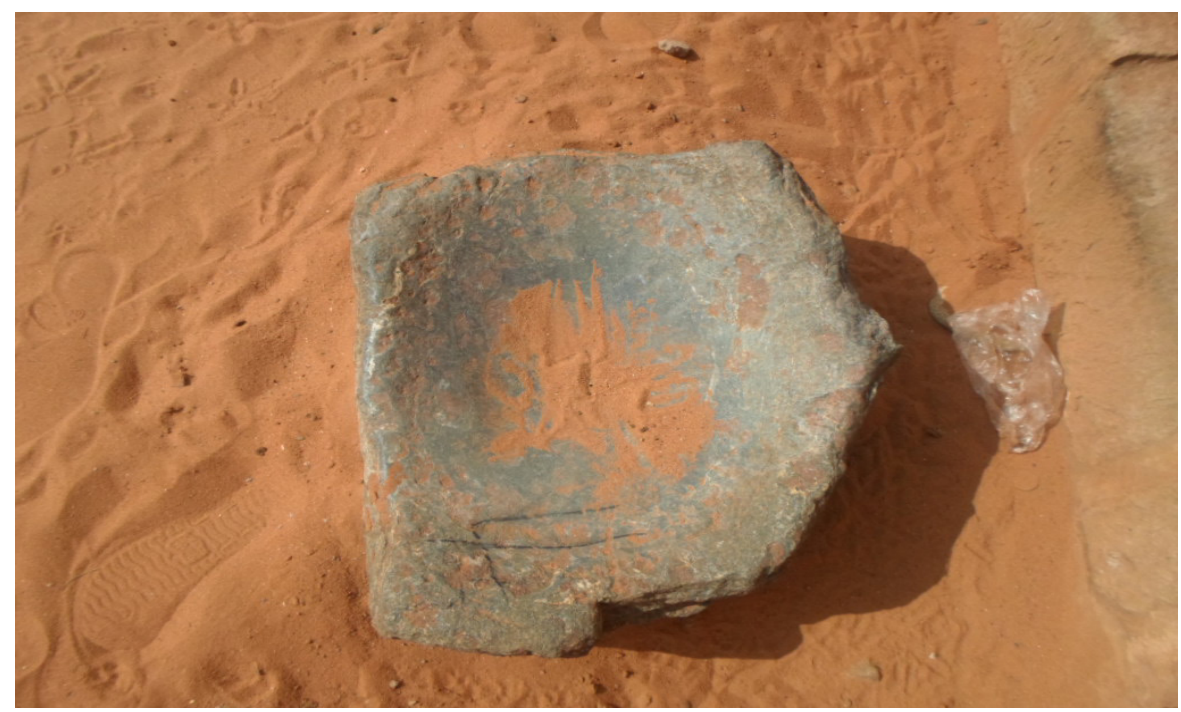

Figure 5: One of several stone troughs used to hold water/food for domesticated animals.

The use of stone blocks as whetting edge tools is common in the research area despite the commonality of hand operated mechanical devices for that purpose. Nuumo Tettey Abladu Anson (pers. com. $3^{\text {rd }}$ July, 2016), a subsistence farmer by occupation intimated that it was common practice among local croppers to use large stone blocks to sharpen the cutting edges of their cutlasses, hoes, axes and 
other tools which required sharp cutting edges to facilitate their effective use. Stone blocks utilized for this purpose were mostly located on their farmsteads. However, a few were also discovered inside or close to house compounds.

The Dangme were thoroughly proficient, highly skilled and adept at constructing agricultural terraces attested by the several well laid out courses of free standing dry stone walling along the slopes and below their hilltop encampments at Shai and Sega Hill. Each course consisted of hundreds of stone blocks of no identifiable shape or size. A few of the terraces, especially those along the very edgy slopes sometimes consisted of more than one course and still stand intact after several centuries of constant exposure to exfoliation and the other vagaries of tropical weather conditions. This method and design of constructing agricultural terraces appeared to have been embraced by other Dangme groups like the Shai settled in the interior. In a paper presented by Anquandah (1987: 19), he noted that "during the $19^{\text {th }}$ century construction of agricultural terraces with dry stone walling and the process of urbanization was initiated in the Shai areas and further expanded in the following centuries".

The Dipo puberty rite is the most important socio-religious event in Dangmeland and constitutes an integral aspect of traditional Dangme culture. Oral traditional data gathered by Marijke Steegstra (2005) indicates that Dipo had its antecedence in antiquity and that the various rites associated with its practice were initiated by the female deity Nana Kloweki. In the past, in some Dangme communities like Krobo, failure to successfully pass the cleansing/purification rites and rituals resulted in the young girl and her family being bastardized or ostracized from the community. Celebrated annually between March and June in most Dangme towns, Dipo is a "rites des passage" for female adolescents. In theory, "Dipo" acted as a check against teenage pregnancy prior to marriage and ensured that families exercised considerable control on the matrimonial process to guarantee social stability in the community. It is common belief among Dangmes that successfully passing the Dipo puberty rite automatically transitions the tutee spiritually and physically from one stage of life to another. During the period of seclusion from their families and society which lasted about two years in the past, tutees were also taken through a process of traditional nurturing (social and cultural history education), child nurturing and upbringing, home keeping and cooking. Other areas of nurture included family and matrimonial education, introduction to crafts such as potting and bead production, Hayo dancing and Klama song recitations. During the final supplicatory rites, the tutees are made to sit three times on a flat almost circular sacred ritual stone called tegbete (also called the Kloweki rock) by the Dipo priestess (se woyo). It is worth noting that the tegbete stone is itself seated on a 
number of smaller stones laid out in a circular formation inside the Kloweki shrine which houses the Dipo deity. Inability of a tutee to rise from the tegbete indicated she was either not a virgin or was secretly pregnant at the time of undertaking the rite. When that occurred, special pacification rites needed to be performed on her behalf. According to Dangme custom, one's inability to perform the required propitiation and appeasement rites could invoke curses from the deity.

Perhaps, my encounter with aunty Ayah Amouku, a revered 77-year-old traditional medical practitioner and birth attendant can be described as the most illuminating and informative interaction during the ethnographic research. An indigene of Kpone with over 45 years experience in ethno-medical practice, her in-depth knowledge of medicinal herbs was mind boggling. She is credited with over 65 successful childbirths and renowned for her curative prowess at remedying most gynecological, prenatal and postnatal disorders in the community. Ayah Amouku (pers. com. $21^{\text {st }}$ July, 2016) recounted that as a teen undertaking a fiveyear apprenticeship under one Nene Korkor Abadge at Osudoku, she witnessed several minor surgical operations involving the use of specialized stone blades which were used to create incisions across specific areas of the body into which herbal concoctions with medicinal properties were inserted to effect cure of some physical ailments She indicated that in the past, a variety of stone blades were also used in achieving facial and body scarification marks. She intimated that prior to cauterizations, the surgical blades, which measured approximately $8 \mathrm{~cm} \times 4 \mathrm{~cm}$ were either first steamed in boiling water or overhung over smokeless burning charcoals for several minutes, purposely to sterilize them, after which they were wrapped in clean damp white calicos to cool. She further intimated that prior to the popularization of Western orthodox surgical procedures, most traditional medical practitioners in Dangme-land used stone blades to undertake minor surgical procedures and that unlike metal blades, incisions achieved with stone blades healed faster and left no physical scars on the affected area after healing.

Stones are also important utility items used inside the shrines of some revered deities in the research area. At Kpone for example, a shrine dedicated to the Gao and Aya deities were externally enclosed with free-standing stone walling from the basal to about the shoulder level and overlaid with woven palm fronds. After making two schnapp bottles offering to the priest, the author was allowed an inside view of the shrine on condition that no snapshots would be taken. Stones were also used as devices to vertically support a number of local earthen pots and bowls laid out in a circular formation before the fetish. Nii Atobie Oti (pers. com. $3^{\text {rd }}$ July, 2017), one of two wolomo's (traditional priests) interviewed asserted that for purposes of purity and sanctity, the pots together with their contents which among 
other things contained water, herbs and tree barks were never to be placed on the ground. The other derivatives of the pot were not divulged because the author was neither an acolyte nor an inductee of the cult. Another stone of interest inside the shrine was a large rock-bed on which otoo (meal of mashed yam mixed with palm oil and boiled eggs) and occasionally animals were offered to the deity to appease the gods, atone for sins and sometimes reverse individual and community curses.

In spite of the popularity of kerosene, gas and electric cookers in the research area, several families and commercial food vendors continue to use traditional stone hearths to prepare foods like kenkey and banku. According to all the respondents, the use of these traditional cookers extended into antiquity, long predating the arrival of Europeans. The cookers usually comprised three free-standing stones of equal height arranged in a triangular formation to support a cooking pot. Each of the stones had flat bases which enabled them stand upright. Fired firewood and charcoal were passed between two of the stones to heat the pot (fig. 6).

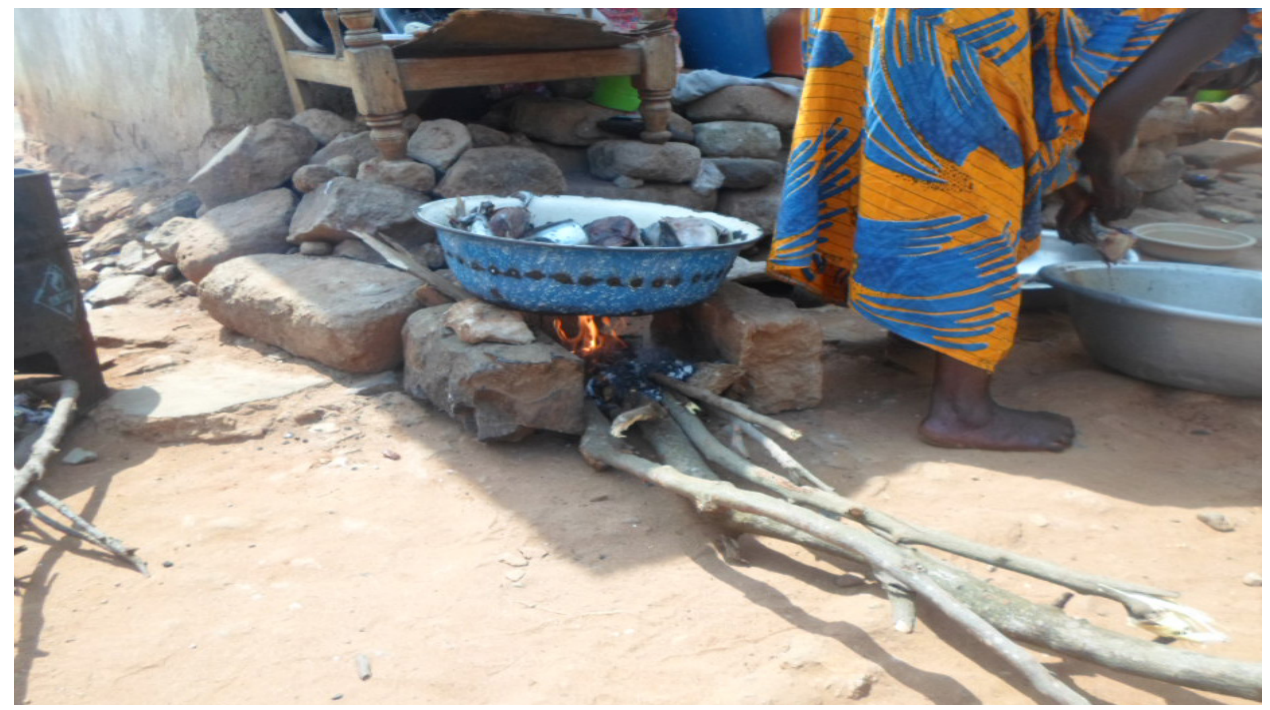

Figure 6: A stone hearth cooker in use at Kpone (Picture: Author)

\section{Conclusion}

Stone probably constituted the most important natural resource which enabled various Dangme populations settle in the research areas to adapt to their environment. Several tool types made out of stone also facilitated the exploitation of a variety of resources in the study areas. For example, fishing, crop farming, 
Biveridge, F./Legon Journal of the Humanities Vol. 30.2 (2019)

tapping and hunting, the four major vocations of the people all depended on the use of stone tools. Stones were also exploited for other purposes including in traditional religion, medicine and architecture. The piling of stones at vantage points around their encampments is an indication that stone constituted a cheap but effectual preemptive weapon used by the people to defend and sometimes attack slavers who actively operated in the region during the Trans Atlantic slave era (1620-1807).

The exploitation of stone for the above purposes has diminished significantly over the last century due primarily to Christianity, globalization and modernism. For example, the use of stone as fish and game entrapments is currently non-existent in the study areas. However, the use of stones as devices for sharpening cutting tools like cutlasses and axes, for pulverizing medicinal plants, in traditional worship and for cooking is still a prominent practice among the indigene population. 


\section{References}

Anquandah, James. (1979). Accra plains archaeological and historical project. Nyame Akuma.No. 15 (23-37)

Anquandah James. (1982). Rediscovering Ghana s past. London: Longman Group. Anquandah, James. (1986). Ethnoarchaeological clues to Ghana's great past. Universitas 8, 113-130. Legon

Anquandah, James. (1987). Accra Plains Dangme-land- A Study on Ethno archaeology and Iron Age Sites. Nyame Akuma, 21, 27-34.

Anquandah, James. (1996). Accra plains Dangme-land: A case study of the Eclectic Approach to archaeological and Historical Studies. FASS Bulletin.

Barbot, John. (1732). A Description of the Coast of North and South Guinea, Churchills collection of voyages and travels. London.

Biveidge, Fritz. (2005). An archaeological investigation of the Kpone coastline and its implications for understanding the Coastal Dangme. (Unpublished Master of Philosophy Thesis). Department of Archaeology and Heritage Studies, University of Ghana, Leegon.

Boahen, Adu Albert. (1977). Ghana before the coming of Europeans. Ghana Social Science Journal, 4, 94.

Bosman, William. (1705). Accurate description of the Coast of Guinea. London: Frank Cass.

Dickson, K. B and Benneh, K. (1973). A new geography of Ghana. London: Longman Group.

Fagan, Brian. (2016). World prehistory, A brief Introduction. New Jersey: Pearson Prentice Hall.

Gblerkpor, William. (2005). An Archaeological Investigation of the Krobo Mountain Dry-Stone Terraces. (Unpublished Master of Philosophy Thesis). Department of Archaeology and Heritage Studies, University of Ghana, Legon.

Joukowsky, Martha. (2015). A Complete Manual of Field Archaeology. New Jersey: Prentice-Hall, Inc. Englewood Cliffs.

Kesse, G.O. (1985). The mineral and rock resources of Ghana. Rotterdam: A. A. Balkema Publishers.

Kpone Traditional Affairs. (1985). (C.S.O. 21/22/1421. 1985. Kpone Traditional Council) Kpone.

Kropp-Dakubu, M.E. (1976). The contribution of linguistics to the study of 
Biveridge, F./Legon Journal of the Humanities Vol. 30.2 (2019)

Ghanaian history. Proceedings of the Seminar on Ghanaian Historiography and Historical Research. 20-22 May, 1976 (Ed.) J.O. Hunwick. (26-42).

Meredith, Henry. (1812). An account of the Gold Coast of Guinea. London: Frank Cass.

Nicholas, Toth and Schick, Cathy. (2010). The evolution of humanity. In C. Scarre (Ed.). The human past: World prehistory and the development of human societies. London: Thames and Hudson.

Oboli, H.O.N. (1998). A new outline Geography of West Africa. London: Harrap Books.

PRAAD (Public Records and Archives Administration Department) Certificate of Authentication No. 000372. Accra.

Sharer, R. J. and Ashmore, Wendy. (2017). Archaeology: Discovering our past. California: Mayfield Publishing Company.

Steegstra, Marijke. (2005). Dipo and the politics of culture in Ghana. Accra: Woeli Publications Services.

\section{Personal Communication}

Ayah Amouku. 21 $1^{\text {st }}$ July, 2016

Attiapa Otetse. $27^{\text {th }}$ July, 2017

John Agbo Opata. 16 $6^{\text {th }}$ July, 2016

Mooko Ablade. 26 $6^{\text {th }}$ June, 2016

Nene Abladu Attiope. 26 ${ }^{\text {th }}$ June, 2016

Nene Oglietse. 14 ${ }^{\text {th }}$ June, 2016

Nii Afum Atteh. $2^{\text {nd }}$ May 2017

Nii Atobie Oti. $3^{\text {rd }}$ July, 2017

Nii Tetteh Angmo. $27^{\text {th }}$ May, 2017

Nuumo Tettey Abladu Ansaon. $3^{\text {rd }}$ July, 2016 